Revista de Metalurgia 50(4)

October-December 2014, e029

ISSN-L: 0034-8570

doi: http://dx.doi.org/10.3989/revmetalm.029

\title{
Effect of microstructure on the impact toughness of high strength steels
}

\author{
Isabel Gutiérrez \\ CEIT and TECNUN (University of Navarra) \\ Paseo de Manuel Lardizábal 15, 20018, Donostia-San Sebastián, Spain \\ Presented at the Workshop "Advanced Steels 2014", 18-19 September 2014, Madrid, Spain \\ corresponding author: igutierrez@ceit.es
}

Submitted: 17 September 2014; Accepted: 29 September 2014; Available On-line: 13 November 2014

\begin{abstract}
One of the major challenges in the development of new steel grades is to get increasingly high strength combined with a low ductile brittle transition temperature and a high upper shelf energy. This requires the appropriate microstructural design. Toughness in steels is controlled by different microstructural constituents. Some of them, like inclusions, are intrinsic while others happening at different microstructural scales relate to processing conditions. A series of empirical equations express the transition temperature as a sum of contributions from substitutional solutes, free nitrogen, carbides, pearlite, grain size and eventually precipitation strengthening. Aimed at developing a methodology that could be applied to high strength steels, microstructures with a selected degree of complexity were produced at laboratory in a Nb-microalloyed steel. As a result a model has been developed that consistently predicts the Charpy curves for ferrite-pearlite, bainitic and quenched and tempered microstructures using as input data microstructural parameters. This model becomes a good tool for microstructural design.
\end{abstract}

KEYWORDS: Charpy model; Mechanical properties; Microalloying; Microstructure; Toughness

Citation / Cómo citar este artículo: Gutiérrez, I. (2014) "Effect of microstructure on the impact toughness of high strength steels". Rev. Metal. 50(4): e029. doi: http://dx.doi.org/10.3989/revmetalm.029

RESUMEN: Efecto de la microestructura en la tenacidad al impacto en aceros de elevada resistencia mecánica. El desarrollo de nuevos grados de acero se tropieza con frecuencia con la necesidad de incrementar la resistencia mecánica al mismo tiempo que se reduce la temperatura de transición dúctil-frágil y se eleva la energía del palier dúctil. Hacer frente a este reto requiere un diseño microestructural. La tenacidad en aceros está controlada por diferentes constituyentes microestructurales. Algunos de ellos, como las inclusiones son intrínsecos, pero otros que se manifiestan a diferentes escalas microestructurales dependen de las condiciones de proceso. Existen algunas ecuaciones empíricas que permiten calcular para ferrita-perlita en aceros de bajo carbono la temperatura de transición como suma de contribuciones de elementos en solución sólida, nitrógeno libre, carburos, fracción de perlita, tamaño de grano y, eventualmente precipitación. Con el objeto de desarrollar una formulación aplicable en aceros de alta resistencia mecánica, se han producido en laboratorio microestructuras con un grado de complejidad controlado. Como resultado de este estudio, se ha desarrollado un modelo que reproduce, partiendo de datos microestructurales, las curvas Charpy de un acero microaleado con microestructuras de ferrita-perlita, bainita y de temple y revenido. Este modelo es una herramienta útil para el diseño microestructural.

PALABRAS CLAVE: Microaleación; Microestructura; Modelo Charpy; Propiedades mecánicas; Tenacidad

Copyright: (C) 2014 CSIC. This is an open-access article distributed under the terms of the Creative Commons Attribution-Non Commercial (by-nc) Spain 3.0 License. 


\section{INTRODUCTION}

One of the major challenges in the development of new steel grades is to get increasingly high strength combined with a low ductile brittle transition temperature and high upper shelf energy, $\mathrm{Kv}_{\mathrm{US}}$. This requires a deep knowledge about microstructure and mesotexture effect on material properties, but is not an easy task for microstructures with an increasing degree of complexity in which the strength is controlled by low and high angle boundaries, while toughness depends on the effective grain size or cleavage unit size (D). Cleavage happens usually on $\{001\}$ ferrite planes and the crack deflects at boundaries that can be considered as misorientation dependent energy barriers for propagation. The value of $\mathrm{D}$ was traditionally expressed as an optical ferrite boundary mean linear intercept, but EBSD has revealed that, even for ferrite-pearlite obtained after thermomechanical treatments (Bengochea et al., 1998, Novillo et al., 2005, Bhattacharjee et al., 2004) a relatively high density of low angle boundaries develops. The situation becomes more complex for bainite or martensite. In this context, EBSD techniques become a must to properly quantify the microstructures due to their fineness and particular distribution of low and high angle boundaries (mesotexture). The cleavage unit size is usually computed for boundaries with a misorientation above a certain threshold typically in the $10-15^{\circ}$ (Díaz-Fuentes et al., 2003). EBSD is a powerful tool for developing appropriate relations between microstructure and mechanical properties, but work still remains in this field.

The first challenge concerns the development of a systematic methodology for EBSD quantification. The angular resolution of the EBSD scans can be theoretically estimated at $1^{\circ}$, but the lowest threshold angle for consistent size quantification was estimated at $2^{\circ}$ (Iza-Mendia and Gutiérrez, 2013). Then, the boundaries were divided into: low $\left(\theta<2^{\circ}\right)$, medium $\left(2^{\circ} \leq \theta<15^{\circ}\right)$ and high $\left(\theta \geq 15^{\circ}\right)$ angle. Low angle boundaries will contribute to the dislocation strengthening, medium and high angle constitute the Hall-Petch contribution. High angle boundaries $\left(\theta \geq 15^{\circ}\right)$ was considered as the threshold angle that defines the cleavage unit size (Díaz-Fuentes et al., 2003).

The second challenge concerns the adaptation of the available formulations (Iza-Mendia and Gutiérrez, 2013; Gutiérrez, 2013). This opens the way to new propositions like the misorientation dependent Hall-Petch coefficient (Iza-Mendia and Gutiérrez, 2013) expressed by the following equation:

$$
\sigma_{d} \cong \alpha M \mu \sqrt{b}\left[\sum_{2 \leq \theta_{i}<15^{\circ}} f_{i} \sqrt{\theta_{i}}+\sqrt{\frac{\pi}{10}} \sum_{\theta_{i} \geq 15^{\circ}} f_{i}\right] d^{-0.5}
$$

in which $f_{i}$ and $\theta_{i}$ are respectively, the relative frequency and the mean misorientation angle (rad) in the interval $i$, determined by EBSD; for ferrite $\alpha=0.3, \mathrm{M}=3, \mu=8 \times 10^{4} \mathrm{MPa}$ and $\mathrm{b}=2.5 \times 10^{-7} \mathrm{~mm}$ and $\mathrm{d}(\mathrm{mm})=\mathrm{MED}_{2}$ is the mean equivalent diameter determined for $\theta \geq 2^{\circ}$.

The optimization of the toughness is a challenge by itself. The microstructure design philosophy works on ductile brittle transition temperature and $\mathrm{K}_{\mathrm{Vus}}$ concepts. In complex steel microstructures, $\mathrm{Kv}_{\mathrm{US}}$ is not directly linked to the grain size, but is mostly influenced by the volume fraction of various phases (Sung et al., 2011). The transition temperature can be expressed in different ways, one of them being the $50 \%$ ductile fracture appearance transition temperature (FATT). For low carbon ferrite-pearlite steels, the FATT is usually related to the steel composition and to a series of microstructural contributions (Irvine et al., 1967, Mintz et al., 1979, Mintz et al., 1994).

The typical formulations were recently extended to bainitic and quenched and tempered microstructures (Gutiérrez, 2013). The aim of this work is now to develop a microstructure based model of the Charpy curves for microstructures with a variable degree of complexity. This model is aimed at being a tool for a better understanding of toughness development in high strength steels.

\section{MATERIALS AND METHODS}

A series of microstructures has been produced through different thermal and thermomechanical sequences (Table 1) on a $\mathrm{Nb}$-microalloyed steel with the composition: $0.15 \mathrm{C}-0.3 \mathrm{Si}-1.4 \mathrm{Mn}-0.012$ $\mathrm{P}-0.037 \mathrm{Al}-0.033 \mathrm{Nb}-0.011 \mathrm{~V}-0.007 \mathrm{~N}$. The steel was reheated at $1200{ }^{\circ} \mathrm{C}$ for 30 minutes in order to dissolve $\mathrm{Nb}$ and subsequently cooled to the deformation temperature for $\mathrm{S} 1$ to $\mathrm{S} 3$ or water quenched for S4 and S5. S1 and S2 correspond respectively to 1-pass and 2-pass plane strain compression (PSC) tests. For S3, a 4-pass horizontal-vertical compression test was applied. After deformation, the specimen was fast cooled $\left(5^{\circ} \mathrm{C} \mathrm{s}^{-1}\right.$ and $15^{\circ} \mathrm{C} \mathrm{s}^{-1}$ respectively for low and high coiling temperatures). Coiling was simulated by 1 hour holding at the coiling temperature $\left(650\right.$ or $\left.300{ }^{\circ} \mathrm{C}\right)$, followed by slow cooling to room temperature. The deformations were always performed at a strain rate of $1 \mathrm{~s}^{-1}$ and the pass-temperatures and applied strains are shown in Table 1.

For S4 and S5 thermal treatments, after water quenching from $1200^{\circ} \mathrm{C}$, the steel was re-austenitised for 15 minutes at $900{ }^{\circ} \mathrm{C}$. For S4, this was followed by immersion into a salt bath at temperatures of 650 or $300{ }^{\circ} \mathrm{C}$, holding for 30 minutes and slow cooling to room temperature. For S5, the steel was water quenched from $900{ }^{\circ} \mathrm{C}$ and tempered for 30 minutes at 650 or $300^{\circ} \mathrm{C}$. 
The microstructural characterisation was performed by FEG-SEM and EBSD. A detailed description of the results can be found in Iza-Mendia and Gutiérrez (2013). Tensile tests were carried out at room temperature with a strain rate of $10^{-3} \mathrm{~s}^{-1}$. Charpy tests were performed at $5.4 \mathrm{~m} \mathrm{~s}^{-1}$ on a Tinius Olsen 84 pendulum impact tester with a maximum capacity of 406 J. For more details see in Gutiérrez (2013).

\section{RESULTS AND DISCUSSION}

A relatively broad range of microstructures can be produced in $\mathrm{Nb}$-microalloyed steels by changing the processing conditions (Fig. 1). Ferrite-pearlite or bainite-pearlite microstructures were produced depending on the coiling temperature. Quenching and tempering produces pearlite-free tempered martensite. Tempering at $650^{\circ} \mathrm{C}$ preserves the morphology of the martensite, but induces the precipitation of carbides.

Considering all these microstructures as a whole a series of microstructural variables can be defined that affect in different ways strength and toughness.

\subsection{Pearlite volume fraction and grain boundary carbides}

Fractography showed that each time the brittle fracture origin was identified, it was associated to carbides. Grain boundary carbides cannot be avoided in most of the thermomechanically
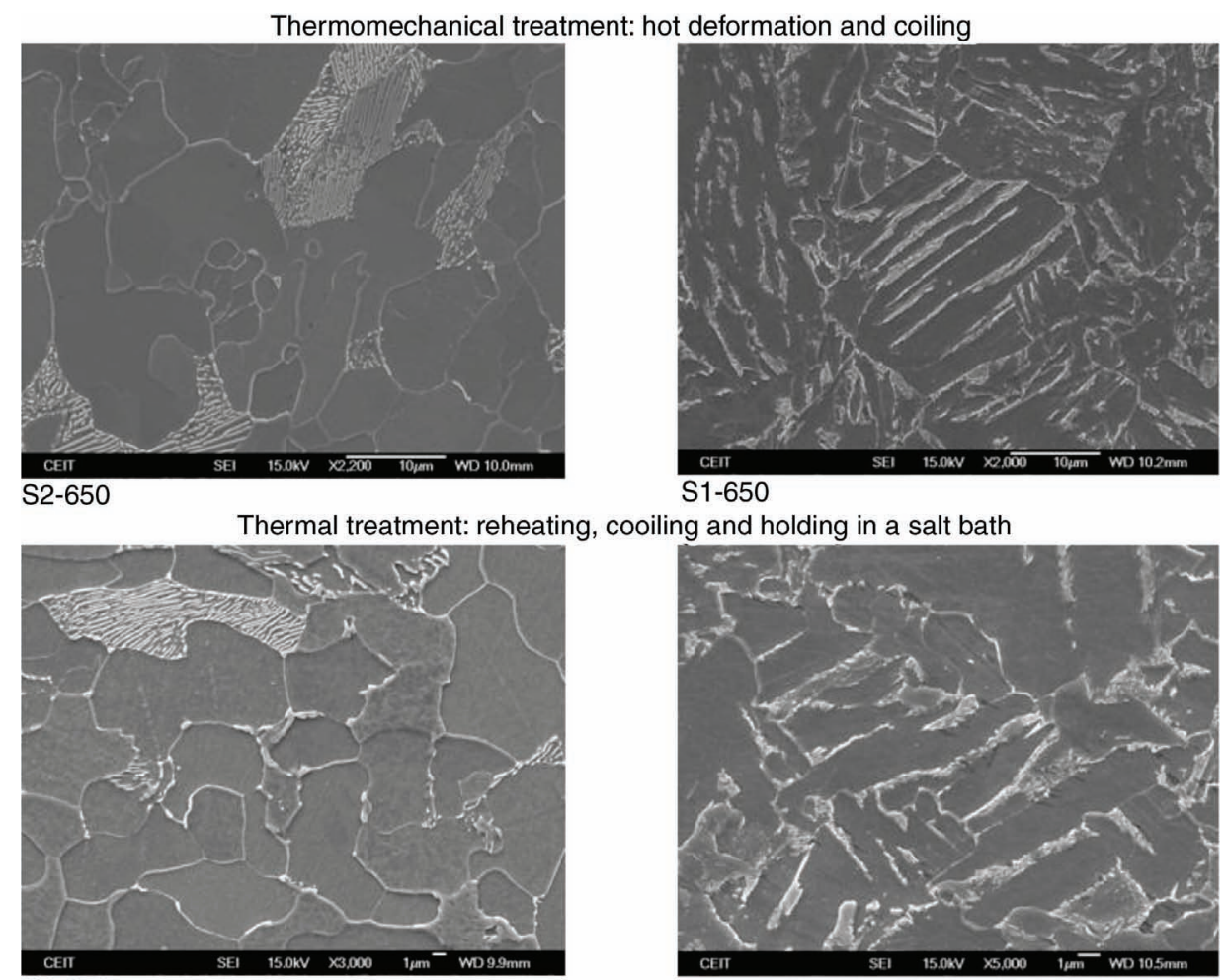

1-650

Thermal treatment: reheating, cooiling and holding in a salt bath

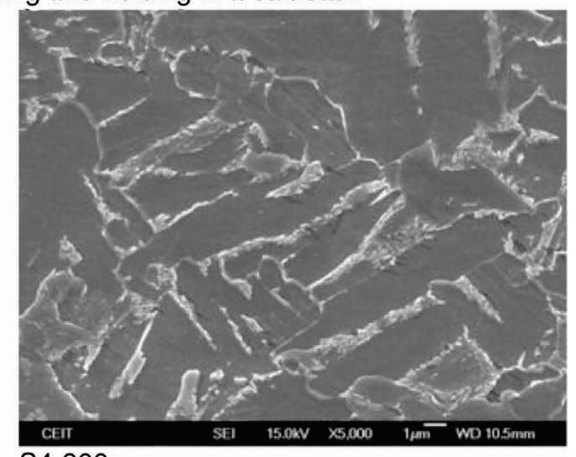

Thermal treatment: quenching and tempering

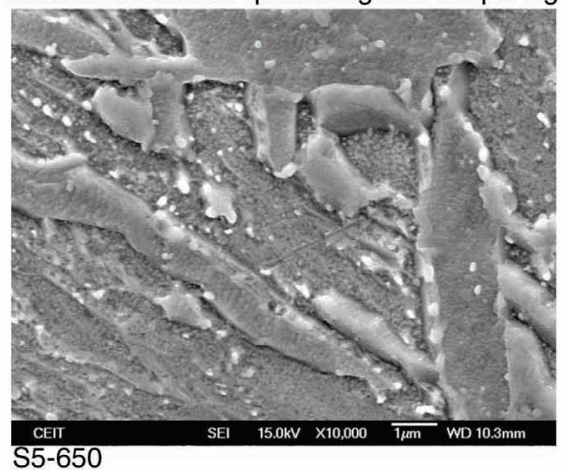

FIGURE 1. Examples of the obtained microstructures. 
processed Nb-microalloyed steels with $\mathrm{F}+\mathrm{P}$ microstructures, but their volume fraction and size depend on the carbon content and processing conditions. The carbide thickness, $\mathrm{t}$, was found to be of around 0.08 for bainitic microstructures and between 0.12 and $0.27 \mu \mathrm{m}$ for ferrite-pearlite. According to these values, their detrimental contribution to the FATT can be estimated to vary between 29 and $58{ }^{\circ} \mathrm{C}$ in this steel when using the following expression proposed by Mintz et al., (1979):

$\Delta \operatorname{FATT}_{\mathrm{c}}\left({ }^{\circ} \mathrm{C}\right)=112 \mathrm{t}^{0.5}$

Pearlite also impairs toughness and its contribution can be expressed according to the following equation (Mintz et al., 1979):

$\Delta \operatorname{FATT}_{\mathrm{p}}\left({ }^{\circ} \mathrm{C}\right)=15(\% \text { pearlite })^{1 / 3}$

Quenched and tempered microstructures (S5) are free of pearlite. For the rest, pearlite volume fraction varies between 14 and $26 \%$ and its detrimental contribution to the FATT can be estimated (Eq. 3) to range between 36 and $44{ }^{\circ} \mathrm{C}$.

\subsection{Boundary misorientation distributions and Grain size}

EBSD maps reveal different boundary misorientation distributions, depending on the microstructure (Fig. 2a) most of them exhibiting a relatively high density of low angle boundaries. For polygonal ferrite these low angle boundaries result from the combination of the K-S orientation relationship and a variant selection during austenite transformation (Bengochea et al., 1998, Novillo et al., 2005). Consequently, even for simple ferrite microstructures, optically measured grain sizes can be significantly different from those obtained by EBSD (Bhattacharjee et al., 2004) unless the appropriate threshold angle and correlations are applied (Iza-Mendia and Gutiérrez, 2013).

The grain boundary misorientation distribution of a bainitic microstructure is the result of the displacive type of transformation. Low angle boundaries are mainly due to sub-units but also to some packet boundaries (Bhadeshia, 2001, Díaz-Fuentes et al., 2003). The boundary misorientation distribution has a characteristic shape, with a high density of low angle boundaries, almost no boundaries at intermediate misorientation angles and two peaks at $\Phi>50^{\circ}$. The relative intensity of these peaks depends on the type of transformation: upper bainite, lower bainite or martensite (Zajac et al., 2005, Altuna and Gutiérrez, 2005).

Low and high angle boundaries contribute to the strength, but groups of closely oriented grains make the crack to propagate on a coplanar manner defining the size of the cleavage unit (Gourgues et al., 2000).
A transverse section of the fracture surface analysed by EBSD in a sample with a bainitic microstructure (S1-300) is shown in Figure 2b. The traces of the $\{001\}$ ferrite lattice planes are indicated, showing that, as expected, the cleavage crack propagates mainly on these planes. The crack deflects at each high angle boundary within the bainitic microstructure. The relation between the FATT and the cleavage unit size determined for the $\mathrm{Nb}$-microalloyed steel by $D=M E D_{15^{\circ}}$, the EBSD mean equivalent diameter for a threshold angle $(\Phi)$ of $15^{\circ}$ has been plot in Figure 2c for the different microstructures in Table 1. When comparing these results to those coming from C-Mn steels (Mintz et al., 1979, Zubialde et al., 2013) a systematic shift to higher transition temperatures results, excepting for S4-650 sample.

\subsection{Nb-rich precipitates of different sizes}

The precipitation strengthening found in $\mathrm{Nb}$ microalloyed steels is usually well described by Ashby-Orowan's equation (Gladman, 1997, Gladman 1999, Kestenbach, 1997). The extra strengthening for F-P microstructures beyond that expected from solutes and grain size (Hall-Petch) can be estimated using the following equation (IzaMendia et al., 2012):

$\Delta \sigma_{y}=\sigma_{y \exp }-\left(54+32 M n+83 S i+k_{H P} d^{-1 / 2}\right)$

with $\sigma_{\text {yexp }}$ the experimental yield strength and the second term the application of a Pickering's type of equation (Pickering, 1978; Pickering, 1993, Gutiérrez and Altuna, 2008) for which only Mn and $\mathrm{Si}$ are considered here given that the concentration of other substitutional elements is negligible in this steel. In equation (4) $d=M E D_{2^{\circ}}$ and $k_{H P}$ is estimated according to Equation (1). The obtained results are shown in Figure 3 a.

For F+P microstructures, (S1-650 to S4-650), the lowest $\Delta \sigma_{\mathrm{y}}(\sim 30 \mathrm{MPa})$ is obtained for the sequence S4-650. Reheating after quenching followed by a long holding stage at $900{ }^{\circ} \mathrm{C}$ induces full precipitation of $\mathrm{Nb}$ and precipitate coarsening. Nb-rich precipitates formed in austenite produce a moderate contribution to yield or tensile strength (Altuna et al., 2012). This explains the position close to C-Mn steels of the point for S4-650 in Figure 3c.

$\mathrm{Nb}$ precipitation in austenite reduces the achievable strengthening contribution. The precipitation strengthening contribution in themomechanically processed samples (S1-650 to S3-650) depends on the sequence and more specifically on the $\mathrm{Nb}$ in solution before transformation to ferrite. The precipitates formed in ferrite are extremely fine $(<3 \mathrm{~nm})$ and produce a precipitation strengthening proportional to the free $\mathrm{Nb}$ in austenite before phase transformation (Herman et al., 1992) that according to Altuna et al., (2012) can be expressed by the following equation: 


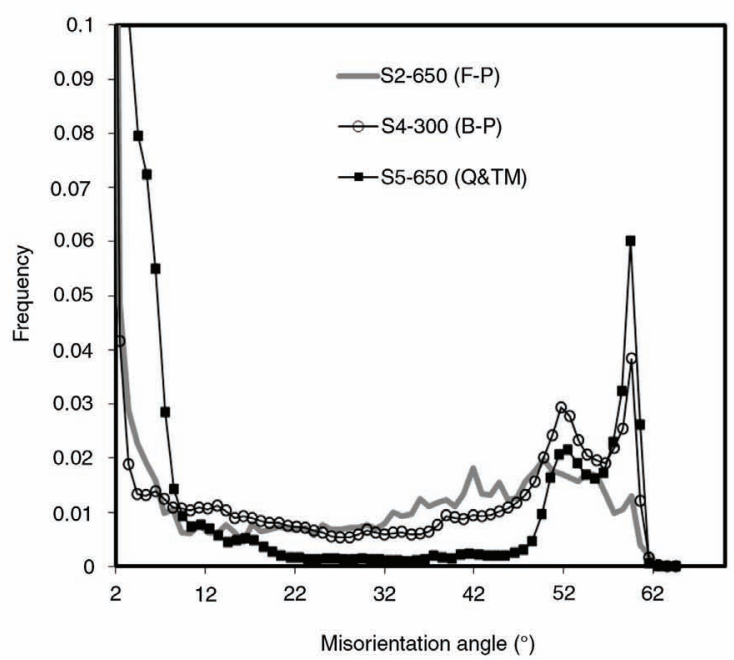

c)

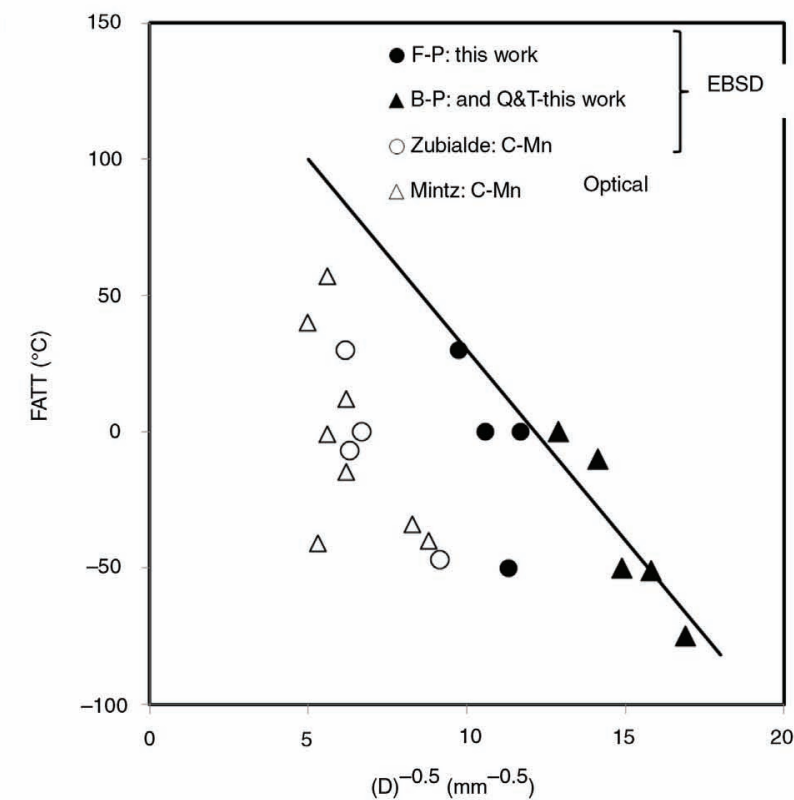

b)
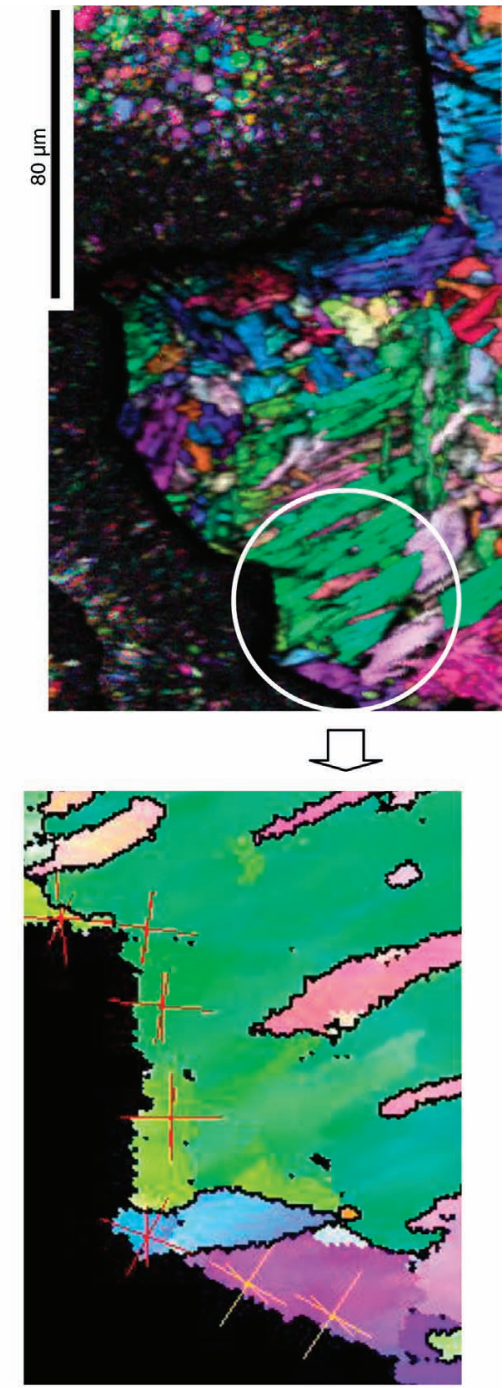

S1-300

FIGURE 2. a) EBSD boundary misorientation angle distribution; b) EBSD images showing IPF+IQ maps and detail of the indicated region showing IPF map, boundaries with misorientation $>15^{\circ}$ and $\{001\}$ planes traces; c) relation between the experimental FATT and the cleavage unit size (Optical: MLI or EBSD: Q $\geq 15^{\circ}$ ) for C-Mn steels and the Nb-microalloyed steel in this work.

$\Delta \sigma_{\mathrm{y}}(\mathrm{MPa})=40+2220 \mathrm{Nb}_{\text {free }}$

with $\mathrm{Nb}_{\text {free }}$ in $\left(\mathrm{wt}^{\%} \%\right)$. Calculating the exact contribution of $\mathrm{Nb}, \Delta \sigma_{\mathrm{yNb}}$, requires using $\mathrm{N}_{\text {free }}$-corrected yield stress (leading to: $\Delta \sigma_{\mathrm{yNb}}=\Delta \sigma_{\mathrm{y}}-5544 \mathrm{~N}_{\text {free}}$ ). In such a case, the slope of the linear regression (Eq. 5) reduces to a value of about $1900 \mathrm{MPa}$ per $\% \mathrm{Nb}_{\text {free }}$ (Altuna et al., 2012).

The S3-650 four pass sequence $\left(\Delta \sigma_{\mathrm{y}} \cong 50 \mathrm{MPa}\right)$ with relatively low finishing temperature was designed for a strain induced precipitation in austenite greater than for $\mathrm{S} 1-650$ and $\mathrm{S} 2-650\left(\Delta \sigma_{\mathrm{y}}\right.$ in the range $80-100 \mathrm{MPa})$. A model for precipitation in austenite (López, 2006) indicates that reheating at $1200{ }^{\circ} \mathrm{C}$ is not able to dissolve $\mathrm{Nb}$ beyond $0.025 \%$. Substituting this value into Equation (5) gives the maximum precipitation strengthening potential of $\mathrm{Nb}$ around $90-95 \mathrm{MPa}$. Not far from the values estimated for $\Delta \sigma_{\mathrm{y}}$ after $\mathrm{S} 1$ and $\mathrm{S} 2-650$ sequences.

The detrimental effect of precipitation strengthening on the FATT for F-P microstructures can be calculated using the following equation (Mintz et al., 1979):

$\Delta$ FATT $_{\text {precipitates }}\left({ }^{\circ} \mathrm{C}\right)=0.5 \Delta \sigma_{\mathrm{y}}$ 
TABLE 1. Summary of the applied thermal and thermomechanical methods to produce the different microstructures

\begin{tabular}{|c|c|c|c|c|c|}
\hline \multirow[b]{2}{*}{ Sequence } & \multirow{2}{*}{$\begin{array}{c}\text { Type of thermal I } \\
\text { Thermomechanical } \\
\text { treatment }\end{array}$} & \multirow{2}{*}{$\begin{array}{c}\text { Deformation } \\
\text { temperatures }\left({ }^{\circ} \mathbf{C}\right) / \text { Applied } \\
\text { strain (+holding time) }\end{array}$} & \multirow[b]{2}{*}{$\begin{array}{l}\text { State of prior } \\
\text { austenite }\end{array}$} & \multicolumn{2}{|c|}{ Type of microstructure $^{d}$} \\
\hline & & & & $\begin{array}{c}\text { Coiling or } \\
\text { tempering at } 650{ }^{\circ} \mathrm{C}\end{array}$ & $\begin{array}{c}\text { Coiling or } \\
\text { tempering at } 300{ }^{\circ} \mathrm{C}\end{array}$ \\
\hline S1 & $\mathrm{PSC}^{\mathrm{a}}$ & $1100 / 0.5(+5 \mathrm{~s})$ & Rex & F-P & $\mathrm{B}$ \\
\hline S2 & $\mathrm{PSC}^{\mathrm{a}}$ & $\begin{array}{c}1100 / 0.5(+5 \mathrm{~s}) \\
950 / 0.3\end{array}$ & Deformed & F-P & B \\
\hline S3 & $\mathrm{H}-\mathrm{V}^{\mathrm{b}}$ & $\begin{array}{c}1100 / 0.4 \\
1050 / 0.4 \\
975^{\circ} \mathrm{C} / 0.4 \\
900^{\circ} \mathrm{C} / 0.5\end{array}$ & Deformed & F-GB & F-B \\
\hline S4 & $\mathrm{TT}^{\mathrm{c}}$ & & & F-P & B \\
\hline S5 & $\mathrm{TT}^{\mathrm{c}}$ & & & Q\&T & Q\&T \\
\hline
\end{tabular}

${ }^{\mathrm{a}}$ Plane Strain Compression; ${ }^{\mathrm{b}}$ Horizontal-vertical compression; ${ }^{\mathrm{c}}$ Thermal Treatment

${ }^{\mathrm{d}} \mathrm{F}=$ ferrite, $\mathrm{P}=$ pearlite, $\mathrm{B}=$ bainite, $\mathrm{GB}=$ granular bainite, $\mathrm{M}=$ martensite, $\mathrm{Q} \& \mathrm{~T}=$ tempered martensite.

Substituting the $\Delta \sigma_{\mathrm{y}}$ values in Figure $3 \mathrm{a}$ into this equation, $\Delta \mathrm{FATT}_{\text {precipitates }}$ will range from $\sim 10$ to $45^{\circ} \mathrm{C}$, depending on the $650^{\circ} \mathrm{C}$ sequence.

\subsection{Transformation dislocation density}

The presence of $\mathrm{Nb}$ in solution before transformation increases the hardenability of the steel, and quite frequently quasi-polygonal and non-polygonal ferrite microstructures are obtained in Nb-microalloyed steels under cooling conditions that would produce equiaxed ferrite in C-Mn steels, but here a low coiling temperature was deliberately applied to get bainite. A displacive transformation produces dislocated substructures with an additional strength that depends on transformation temperature (Bhadeshia, 2001) or tempering temperature (Malik and Lund, 1972) (Fig. 3b). For the two quenched and tempered samples (S5-300 and S5-650), the $\Delta \sigma_{y}$ from Equation (4) has also been plot. Given that, the martensite start temperature $M_{s} \cong 440{ }^{\circ} \mathrm{C}$ determined by dilatometry is higher than the tempering temperature for (S5-300) the $\Delta \sigma_{\mathrm{y}}$ has been assigned the $M s$. Tempering at $650^{\circ} \mathrm{C}$ produces a significant decrease of $\Delta \sigma_{\mathrm{y}}$ which, is consistent with the expected behavior.

It is usually assumed that the dislocations resulting from cold working do not contribute too much to the FATT, but there is no information concerning the eventual effect of transformation dislocations present in bainite. As a first approximation, the same coefficient than the precipitation strengthening in Equation (6) was considered, leading to the following expression (Gutiérrez, 2013):

$\Delta$ FATT $_{\text {bainite }}\left({ }^{\circ} \mathrm{C}\right)=0.5 \Delta \sigma_{\mathrm{y}}$

\subsection{Free interstitial elements}

The determination of the content of free interstitial elements as carbon and nitrogen in microalloyed steels is difficult. For ferrite-pearlite, the free $\mathrm{N}$ can be estimated by a combination of hot rolling and coiling models. For bainitic and Q\&T microstructures, it would not be possible to dissociate the effect of interstitial elements from that of dislocations. Nevertheless, taking into account the coefficients usually assigned to this element (Gladman, 1971, Pickering, 1978; Pickering, 1993), a maximum contribution of $39 \mathrm{MPa}$ to the yield strength and of $59^{\circ} \mathrm{C}$ to the FATT results for all $\mathrm{N}$ dissolved in ferrite.

\subsection{Application}

Assuming that in the transition region the fracture energies in the ductile and brittle regions are both independent of the testing temperature and practically equal to the upper, $\mathrm{Kv}_{\mathrm{US}}$, and lower, $\mathrm{Kv}_{\mathrm{LS}}$, shelf energies (Todinov, 2001), a modified law of mixtures given by:

$$
K v=\left(X_{d}\right)^{n} K v_{U S}+\left[1-\left(X_{d}\right)^{n}\right] K v_{L S}
$$

can be applied (Gutiérrez, 2013), with $n=0.7$ and $X_{d}$ being the ductile fraction measured on the fracture surface, that can be expressed by the following empirical equation:

$X_{d}(T)=1-\exp \left[-k\left(\frac{T-F A T T}{100}-\left(\frac{0.69}{k}\right)^{1 / m}\right)^{m}\right]$

with $\mathrm{m}=2.5$ and $k$ that has been deduced for this steel to be a function of the cleavage unit size (in $\mathrm{mm}$ ) of the form:

$$
k=30 \exp \left(-3 \cdot 10^{-4} D\right)
$$

The coefficients $k$ and $m$ define the slope of the Charpy curve in the transition and can vary depending on the steel.

The equation for the FATT (Gutiérrez, 2013) has now been modified by replacing the sum of the contribution from grain boundary carbides and from 
a)

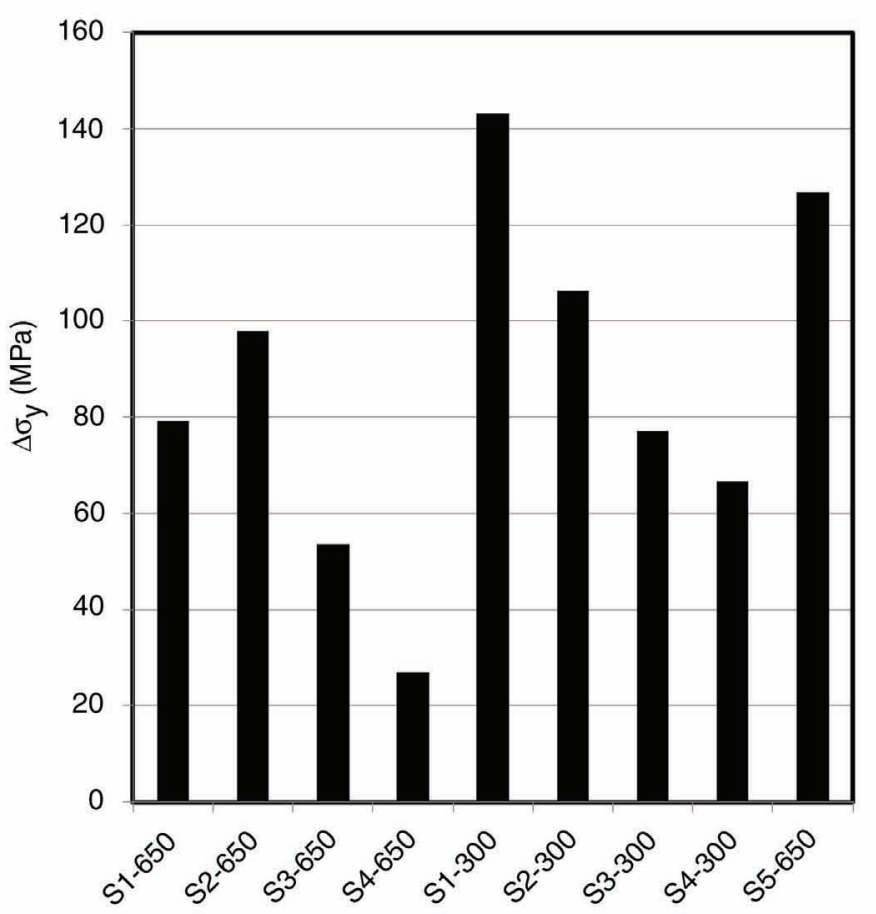

b)

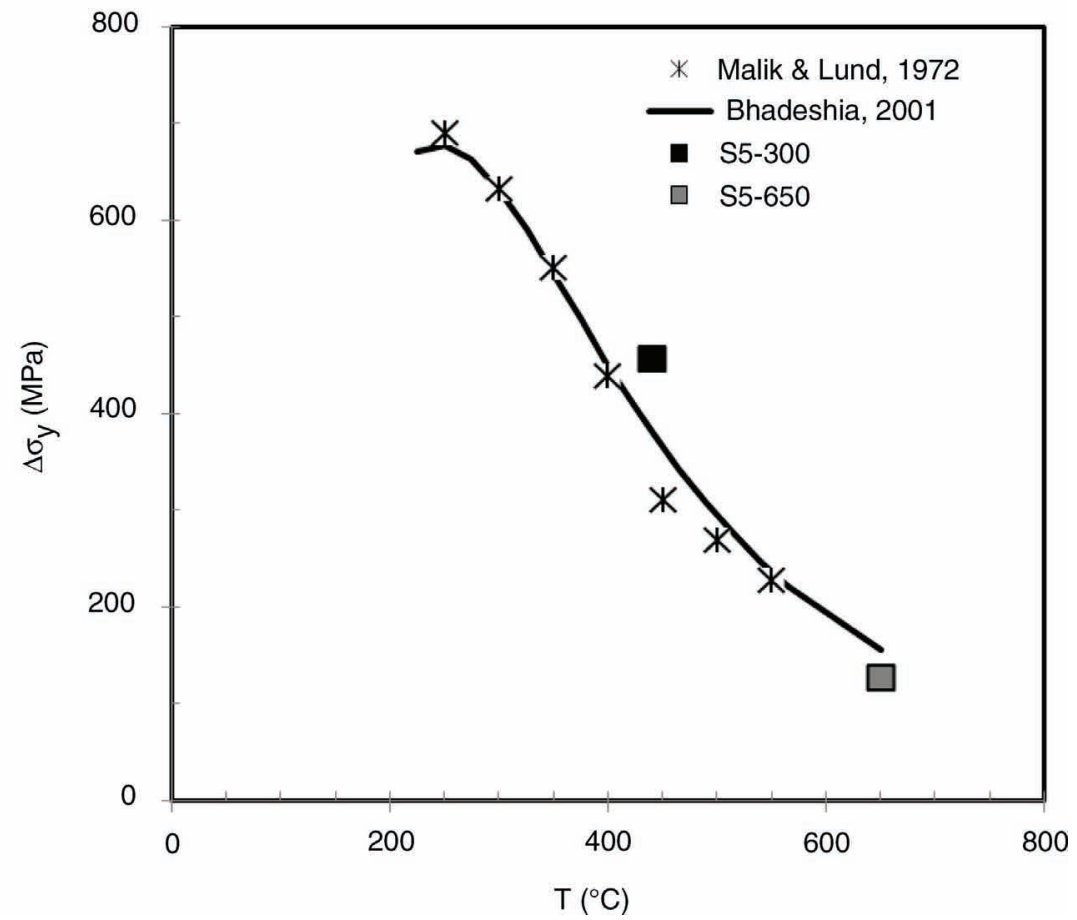

FIGURE 3. Extra yield strength $\left(\Delta \sigma_{y}\right)$ beyond that expected from substutional solutes and grain size (Eq. 5): a) as a function of the applied sequence and b) comparison for Q\&T S5-300 and S5-650 between experimental and expected values.

free nitrogen by a constant term equal to $88^{\circ} \mathrm{C}$, leading to the following expression:

$$
\begin{aligned}
& \text { FATT }\left({ }^{\circ} \mathrm{C}\right)=88-11 \mathrm{Mn}+42 \mathrm{Si}+15 \\
& (\% \text { pearlite })^{1 / 3}+0.5 \Delta \sigma_{\mathrm{y}}-14(\mathrm{D})^{-0.5}
\end{aligned}
$$

For this steel no splitting occurred and the following empirical equation:

$$
\begin{aligned}
& \mathrm{KV}_{\mathrm{US}}(\mathrm{J})=7.3510^{5}(88-11 \mathrm{Mn}+42 \mathrm{Si}+15 \\
& \left.(\% \text { pearlite })^{1 / 3}+0.5 \Delta \sigma_{\mathrm{y}}\right)^{-1.59}
\end{aligned}
$$



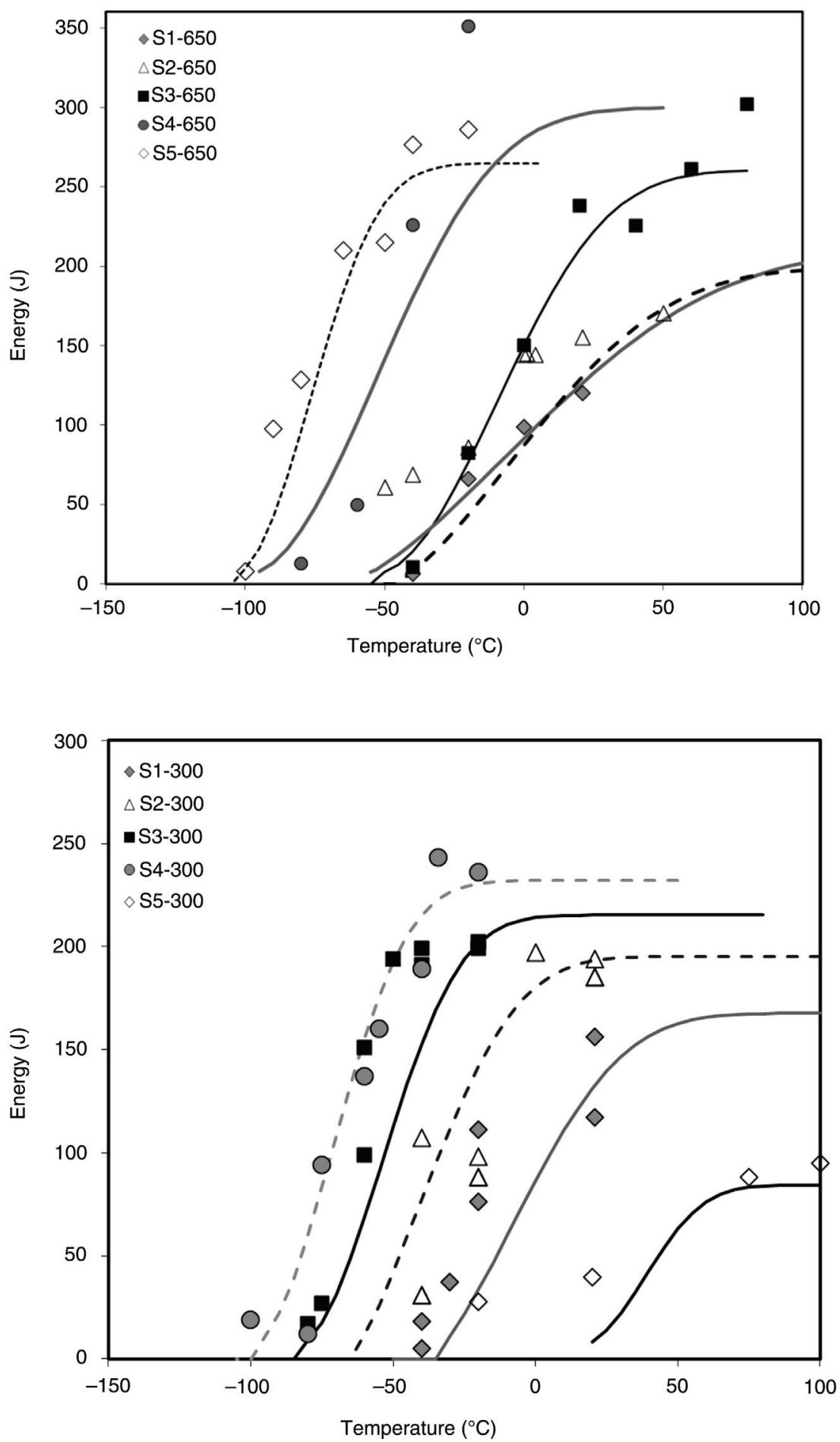

FIGURE 4. Experimental Charpy curves and predictions of the model (lines). Some FATT correction factor was required for some curves in order to obtain a better fit with experiment. This correction factor is indicated in Table 2.

has been deduced that expresses $\mathrm{KV}_{\mathrm{US}}$ as the sum of contributions to the FATT (Eq. 11) other than grain size.

Equation (8) to Equation (12) together with Equation (4) are the basic equations of the proposed model that allows calculating the Charpy curves for the different microstructures in Table 1 . The results shown in Figure 4 have been calculated using the following equation:

$$
\begin{aligned}
& \text { FATT }\left({ }^{\circ} \mathrm{C}\right)=(88+\Delta \text { FATT }-11 \mathrm{Mn}+42 \mathrm{Si}+15 \\
& (\% \text { pearlite })^{1 / 3}+0.5 \Delta \sigma_{\mathrm{y}}-14(\mathrm{D})^{-0.5}
\end{aligned}
$$


TABLE 2. Evaluation of the deviation of the FATT from the model predictions $(\Delta$ FATT)

\begin{tabular}{lcc}
\hline Sequence & $\begin{array}{c}\text { Coiling or } \\
\text { tempering at } \mathbf{6 5 0}\end{array}$ & $\begin{array}{c}{ }^{\circ} \mathbf{C} \\
\text { Cempering at } \mathbf{3 0 0}\end{array}$ \\
\hline S1 & $\mathbf{C}$ \\
S2 & 0 & 0 \\
S3 & 0 & 0 \\
S4 & 20 & 0 \\
S5 & -15 & 0 \\
\hline
\end{tabular}

which differs from Equation (11) in the term $\Delta$ FATT that is used here as an error term to express the deviation between the model predictions (Eq. 11) and the experimental data.

The proposed model describes very well most of the experimental curves, as can be seen in Figure 4. A deviation happens for two $\mathrm{F}+\mathrm{P}$ and one $\mathrm{Q} \& \mathrm{~T}$ (S5- 650) microstructures (Table 2). For these three cases, the predicted FATT requires a correction factor, $\triangle F A T T$, in an interval of $\pm 20^{\circ} \mathrm{C}$ which is very reasonable taking into account the normal scatter for this parameter (Mintz et al., 1979).

\section{CONCLUSIONS}

The proposed model describes reasonably well the Charpy curves for a relatively broad range of microstructures (ferrite-pearlite, bainite and quenched and tempered) obtained in the same $\mathrm{Nb}$-microalloyed steel.

This model is probably not of general application because some of the parameters defining the Charpy curve, for example the upper shelf impact energy that has been expressed as the sum of FATT terms, excepting grain size term, will certainly be affected by different correlations when changing the steel. Nevertheless, it constitutes an interesting tool for microstructural design and its formulation could open new perspectives.

\section{ACKNOWLEDGMENTS}

The author would like to acknowledge assistance in performing the experimental tests from E. Alonso, S. Martin and J. Urbieta. Part of this work was performed under a research grant from the European Commission RFSR-CT-2005-00029 and Ministerio de Educación y Ciencia MAT200523928-E.

\section{REFERENCES}

Altuna, M.A., Gutiérrez, E.I. (2005). Relación microestructuracomportamiento mecánico en estructuras bainíticas. Rev. Metal. 41 (5), 357-364. http://dx.doi.org/10.3989/revmetalm. 2005.v41.i5.225.

Altuna, M.A., Iza-Mendia, A., Gutiérrez, I. (2012). Precipitation of $\mathrm{Nb}$ in ferrite after austenite conditioning. Part II: Strengthening Contribution in High-Strength Low-Alloy
(HSLA) Steels. Metall. Mater. Trans. A 43 (12), 4571-4586. http://dx.doi.org/10.1007/s11661-012-1270-x.

Bengochea, R., López, B., Gutiérrez, I. (1998). Microstructural evolution during the austenite to ferrite transformation from deformed austenite. Metall. Mater. Trans. A 29 (2), 417-426. http://dx.doi.org/10.1007/s11661-998-0122-1.

Bhadeshia, H.K.D.H. (2001). Bainite in Steels. Second Edition, IOM Communications Ltd, London.

Bhattacharjee, D., Knott, J.F., Davis, C.L. (2004). CharpyImpact-Toughness prediction using an "effective" grain size for thermomechanically controlled rolled microalloyed steels. Metall. Mater. Trans. A 35 (1), 121-130. http:// dx.doi.org/10.1007/s11661-004-0115-7.

Díaz-Fuentes, M., Iza-Mendia, A., Gutiérrez, I. (2003). Analysis of different acicular ferrite microstructures in low carbon steels by EBSD. Study of their toughness behavior. Metall. Mater. Trans. A 34 (11), 2505-2516. http://dx.doi. org/10.1007/s11661-003-0010-7.

Gladman, T., Holnes B, McIvor, I.D. (1971). Effect of secondphase particles on strength, toughness and ductility. Proc. Conf. Effect of second-phase particles on the mechanical properties of steel, Corporate Laboratories of the British Steel Corporation and the Iron and Steel Institute, Scarborough, London, pp. 67-78.

Gladman, T. (1997). The Physical Metallurgy of Microalloyed Steels. Institute of Materials, London, England, p. 55.

Gladman, T. (1999). Precipitation hardening in metals. Mater. Sci. Technol. 15 (1), 30-36. http://dx.doi.org/10.1179/ 026708399773002782.

Gourgues, A.F., Flower, H.M., Lindley, T.C. (2000). Electron backscattering diffraction study of acicular ferrite, bainite, and martensite steel microstructures. Mater. Sci. Technol. 16 (1), 26-40. http://dx.doi.org/10.1179/026708300773002636.

Gutiérrez, I. (2013). Effect of microstructure on the impact toughness of $\mathrm{Nb}$-microalloyed steel: Generalisation of existing relations from ferrite-pearlite to high strength microstructures. Mat. Sci. Eng. A 571, 57-67. http://dx.doi. org/10.1016/j.msea.2013.02.006.

Gutiérrez, I., Altuna, A. (2008). Work-hardening of ferrite and microstructure-based modelling of its mechanical behaviour under tension. Acta Mater. 56 (17), 4682-4690. http:// dx.doi.org/10.1016/j.actamat.2008.05.023.

Herman, J.C., Donnay, B., Leroy, V. (1992). Precipitation Kinetics of Microalloying Additions during Hot-rolling of HSLA Steels. ISIJ Int. 32 (6), 779-785. http://dx.doi. org/10.2355/isijinternational.32.779

Irvine, K.J., Pickering, F.B., Gladman, T. (1967). Grain-Refined C-Mn Steels. JISI, 205, 161-182.

Iza-Mendia, A., Altuna, M.A. Pereda B., Gutiérrez, I. (2012). Precipitation of $\mathrm{Nb}$ in Ferrite After Austenite Conditioning. Part I: Microstructural Characterization. Metall. Mat. Trans. A 43 (12), 4553-4570. http://dx.doi.org/10.1007/ s11661-012-1395-y.

Iza-Mendia, A., Gutiérrez I. (2013). Generalization of the existing relations between microstructure and yield stress from ferrite-pearlite to high strength steels. Mat. Sci. Eng. A 561 (20), 40-51. http://dx.doi.org/10.1016/j.msea.2012.10.012.

Kestenbach, H.J. (1997). Dispersion hardening by niobium carbonitride precipitation in ferrite. Mater. Sci. Technol. 13 (9), 731-739. http://dx.doi.org/10.1179/026708397790290308.

López, B. (2006). Characterisation and Modelling of Strain Induced Precipitation, ECSC Final Report: Contract No 7210-PR/350. CAMSIP, by Scott, C., Rose, A., Soenen, B., Lopez, B., Paul, G., Published Technical Steel Research, EUR 22431, ISBN 92-79-03740-4.

Malik, L., Lund, J.A. (1972). A Study of Strengthening Mechanisms in Tempered Martensite From a Medium Carbon Steel. Metall. Trans. 3 (6), 1403-1406. http://dx.doi.org/ 10.1007/BF02643024

Mintz, B., Morrison, W.B., Jones, A. (1979). Influence of carbide thickness on impact transition temperature of ferritic steels. Mater. Sci. Technol. 6 (1), 252-260. http://dx.doi. org/10.1179/030716979803276246.

Mintz, B., Peterson, G., Nassar A. (1994). Structure-Property Relationships in Ferrite-Pearlite Steels. Ironmak. Steelmak. 21 (3), 215-222. 
Novillo, E., Cotrina, E., Iza-Mendia, A., López, B, Gutiérrez, I. (2005). Factors limiting the achievable ferrite grain refinement in hot worked microalloyed steels materials. Science Forum 500-501, 355-362. http://dx.doi.org/10.4028/www. scientific.net/MSF.500-501.355

Pickering, F.B. (1978). Physical metallurgy and the design of steels. Ed. Applied Science Publishers, p. 10.

Pickering, F.B. (1993). Structure-property relationships in steels. Materials Science and Engineering, Ed. R.W. Cahn, P. Haasen, E.J. Kramer, Vol. 7, Constitution and Properties of Steels, Ed. F.B. Pickering, VCH, p. 47.

Sung, H.K., Shin, S.Y., Hwang, B., Lee, C.G., Lee, S. (2011). Effects of Rolling and Cooling Conditions on Microstructure and Tensile and Charpy Impact Properties of Ultra-Low-Carbon High-Strength Bainitic Steels. Metall. Mat. Trans. A 42 (7), 1827-1835. http://dx.doi.org/10.1007/s11661-010-0590-y.
Todinov, M.T. (2001). An efficient method for estimating from sparse data the parameters of the impact energy variation in the ductile-brittle transition region. Int. J. Fracture 111 (2), 131-150. http://dx.doi.org/10.1023/A:10122126 10024.

Zajac, S., Achwinn, V., Tacke, K.H. (2005). Characterisation and quantification of complex bainitic microstructures in high and ultra-high strength linepipe steels. Materials Science Forum 500-501, 387-394. http://dx.doi.org/10.4028/www. scientific.net/MSF.500-501.387.

Zubialde, R., Uranga, P., López, B., Rodriguez-Ibabe, J.M. (2013). Heterogeneity and microstructural features intervening in the ductile-brittle transition of ferrite-pearlite steels, Conf. Proc. Materials Science and Technology (MS\&T), Montreal, Quebec, Canada, pp. 313-320. 